\title{
EXPLOITATION OF THE DOMESTIC WASTEWATER TREATMENT PLANT BY ACTIVATED SLUDGE IN THE AIRPORT AREA OF THE CITY BEN SLIMANE (MOROCCO)
}

\author{
M. Najy ${ }^{1 *}$, F. Z. Talbi ${ }^{2}$, H. Ech-Chafay ${ }^{1}$, M. Lachhab ${ }^{1}$, M. El Qryefy ${ }^{1}$, D. Belghyti ${ }^{1}$ \\ ${ }^{1}$ Laboratory of Agro-physiology, Biotechnology, Environment and Quality, Department of Biology, Ibn Tofail University, Faculty \\ of Science, BP133, 14000 Kenitra, Morocco \\ ${ }^{2}$ Laboratory Biotechnology and Preservation of Natural Resources, Department of Biology Dhar El Mahraz, Sidi Mohamed Ben \\ Abdellah University, Faculty of Sciences, 30000 Fez, Morocco
}

KEY WORDS: Wastewater, Exploitation, Activated Sludge, Treatment, Ben Slimane

\begin{abstract}
:
Domestic wastewater (toilet water and household water from kitchens) is evacuated in unit or separate networks to the purification station (STEP) in order to eliminate their waste; organic and mineral matter, dissolved and suspended before discharging them into the natural environment or reusing them in irrigation. The main purpose of this work is to operate the wastewater treatment plant in the Ben Slimane Airport area by using activated sludge, this process consists of destroying pollutants and microorganisms by bacteria formed in the clarifier. Moreover, the operation of the station was considered by controlling the sensors installed in each basin to promote their optimization, in addition, the physicochemical analysis was carried out in the STEP laboratory. The results found for the parameters studied showed the very effective reduction of the organic load of the wastewater treatment plant, so these values meet the discharge standards defined by Moroccan legislation.
\end{abstract}

\section{INTRODUCTION}

The sole objective of sanitation was to remove wastewater, vectors of pathogenic microorganisms (bacteria, viruses, parasites, etc.) from urban areas (Renou, 2006). The impact of these urban and industrial effluents on the environment has made it possible to set up purification systems around the world.

According to the Joint Decree of the Minister of the Interior, the Minister of Energy, Mines, Water and the Environment, the Minister of Industry, Trade and New Technologies and the Minister of Crafts $11^{\circ} 2942-13$ of $1^{\circ}$ hija 1434 (October 7 , 2013) fixing the general limit values for discharge into surface or ground water.

Considering the decree $\mathrm{n}^{\circ} 2-04-553$ of 13 hija 1425 (January $24,2005)$ relating to discharges, flows, discharges, direct or indirect deposits in surface or underground water, in particular its article 12. Until now, the stations wastewater treatment plants are designed to remove pollutants of various forms, to protect human health and the environment (Muga and Mihelcic, 2008). Also the aquatic environments must remain free of pollution (da Silva, 2008) while respecting the standards of the quality of the discharged water.

The activated sludge process (ASP) is the most common technique used worldwide for the biological treatment of municipal and industrial wastewater in sewage treatment plants (WWTP) (Nancharaiah and Sarvajith, 2019), allows to eliminate a much of the organic matter (Nguyen, 2014) and nutrients in these waters (Hartley, 2008; He et al., 2018).

The good purification of this process depends on good biological conversion in the biological basins where the degradation of the organic matter by filamentous bacteria takes place, as well as the normal and efficient separation of the sludge at the level of the clarifier (Martins et al., 2004; Olsson, 2012),

Poor extraction of clarified sludge leads to deterioration of settleability, which causes poor operational performance with high treatment cost.

Protecting the ecosystem and the environment is one of the world's concerns. Indeed, the objective of our study, to operate the WWTP in the town of Ben Slimane, requiring increasingly efficient actions, both from a quantitative and qualitative point of view (requirement of standards).

\section{METHODOLOGY}

\subsection{Description of Wastewater Treatment Plant (WWTP)}

The treatment station in the Ben Slimane Airport zone (Lat $33.669207^{\circ}$ Long $-7.240634^{\circ}$ ) located between the city of Benslimane and Mohammedia with a semi-continental temperate variant of the semi-arid climate of transition between the coastal climates subhumid and arid hinterland climates.

The waste water of the population connected, gathered at the pumping station operating in an automated way, when the water reaches a certain level defined by our team, the pumps emigrated in this structure begin to evacuate the raw water towards the pre-treatment station (Figure 1).

The purpose of pre-treatment is to eliminate $40 \%$ of the pollutants contained in the water and to avoid any impediments

\footnotetext{
* Corresponding author
} 
that may occur during the subsequent stages of treatment. It includes: Screening, grit removal-oil removal and grit removal.

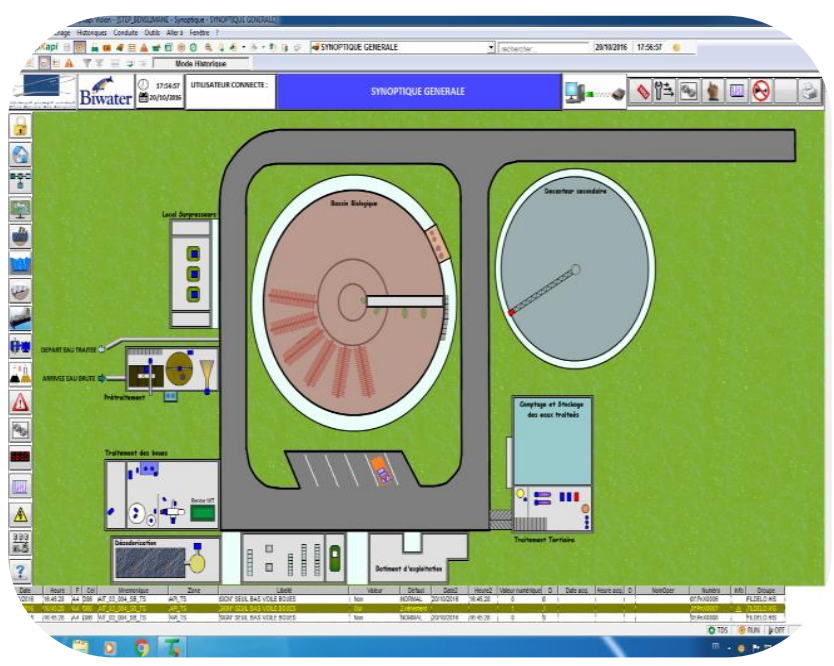

Figure 1. Wastewater treatment system of the WWTP by activated sludge

The biological basin receives water from the pre-treatment component, aimed at breaking down the organic pollutants which occur in the receiving environment. The principle consists of bringing the organic pollutants into contact with the microbial culture. In the first step, the soluble or colloidal contaminants are consumed by the microorganisms which transform them into cellular constituents. The addition of coagulant such as aluminum sulphate (Najy et al., 2019a, $2019 b)$ reacts with colloidal substances, destabilizing the charges according to equations ( 1 and 2 ) and makes it possible to avoid the proliferation of algae in the biological basin. and consequently the development of plant species in the treated water tank.

$$
\begin{aligned}
& \mathrm{Al}_{2}\left(\mathrm{SO}_{4}\right)_{3} .14 \mathrm{H} 2 \mathrm{O} \rightarrow 2 \mathrm{Al}(\mathrm{OH})_{3}+6 \mathrm{H}^{+}+3 \mathrm{SO}_{4}{ }^{2-}+8 \mathrm{H}_{2} \mathrm{O} \\
& \mathrm{Al}_{2}(\mathrm{SO} 4)_{3}+3 \mathrm{Ca}\left(\mathrm{HCO}_{3}\right)_{2} \rightarrow 3 \mathrm{CaSO}_{4}+2 \mathrm{Al}(\mathrm{OH})_{3}+6 \mathrm{CO}_{2}
\end{aligned}
$$

Then, at the secondary settling tank, the microorganisms and other suspended matter will be mechanically separated from the purified water.

\subsection{Study Methods}

The monitoring of a station is carried out at different levels: - online measurements $(\mathrm{pH}$, temperature, flow rates, dissolved oxygen concentration, redox potential, MES) and offline measurements carried out daily (COD, MES, BOD5) on samples averaged at the station inlet and outlet;

- Controls operation, monitoring the quality of aerobic pond sludge and the clarity of the water in the clarifier;

- the control loops on the aeration and $\mathrm{pH}$ system or on the pumps responsible for the recycling / extraction cycle, etc.);

- visually observe the different basins, carry out the settling tests, interpret the measurements to assess the state of the process, run the station (sludge extraction cycle, addition of nutrients, calibrate local control loops), anticipate the behavior of the process and finally detect and locate all the faults, in order to ensure the proper functioning of the treatment plant and to have a quality purified water in accordance with that fixed by our State.
Biological oxygen demand (BOD5): this is the quantity of oxygen ( $\mathrm{mg} / \mathrm{l}$ ) consumed for 5 days by microorganisms during the degradation of organic matter at a temperature of $20^{\circ} \mathrm{C}$ and at 1 'darkness. The principle is to put the raw water samples in vials containing bacteria and then place them in a BOD meter for 5 days. Microorganisms, by degrading the organic matter present in the water, consume oxygen and produce $\mathrm{CO} 2$ thus causing a depression recorded by a pressure gauge (illustration $1)$.

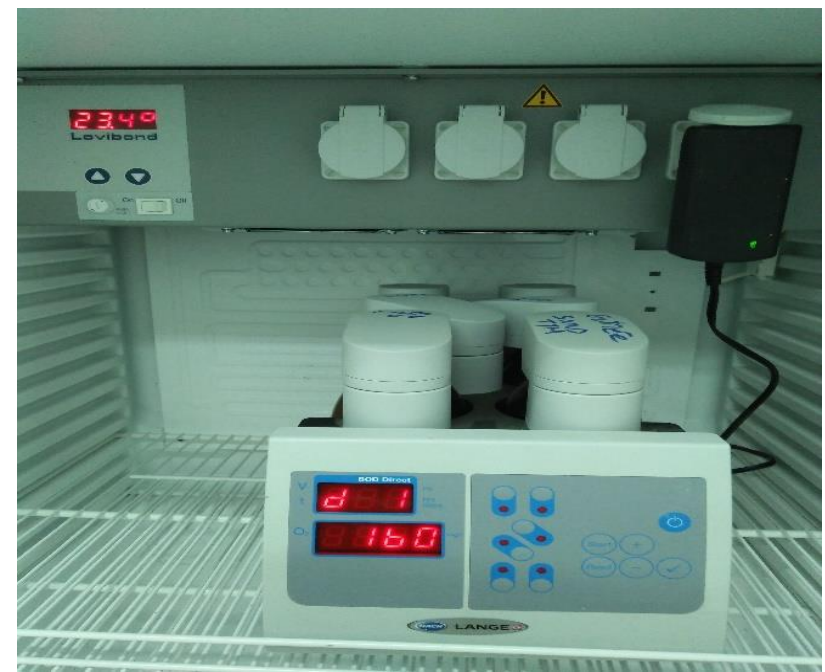

Illustration 1. Biochemical oxygen demand (BOD5) apparatus

\section{OPERATION OF THE STATION}

\subsection{Identification of the Sludge Concentration in the Biological Reactor}

The sludge index, noted "SI", allows the ability of the sludge to settle. It represents the volume occupied by $1 \mathrm{~g}$ of suspended solids sludge after 30 minutes of settling in a $1 \mathrm{~L}$ graduated cylinder with a transparent wall. It is expressed in $\mathrm{mL} / \mathrm{g} \mathrm{SM}$ and is defined by the following formula:

\section{$S I=\frac{V 30 \text { read } * \text { dilution factor }}{\text { Suspended matter }(\mathrm{SM}) \text { biological reactor }}$}

- V30 read: volume of sludge settled in 30 minutes, expressed in $\mathrm{mL} / \mathrm{L}$. The V30 read must be between 100 and $300 \mathrm{~mL}$.

- If $\mathrm{V} 30 \mathrm{read}>300 \mathrm{~mL} / \mathrm{L}$ : additional dilution with wastewater is necessary.

If $\mathrm{V} 30 \mathrm{read}$ (without dilution) $<100 \mathrm{~mL}$ : it is necessary to concentrate the sludge.

- Suspended matter SM biological reactor: concentration of sludge from the biological reactor, expressed in g SS / L.

The settling test, used to calculate the sludge index, is easy to implement and must be carried out on site, protected from light. Calculation of the sludge index requires analysis of the SS concentration. 


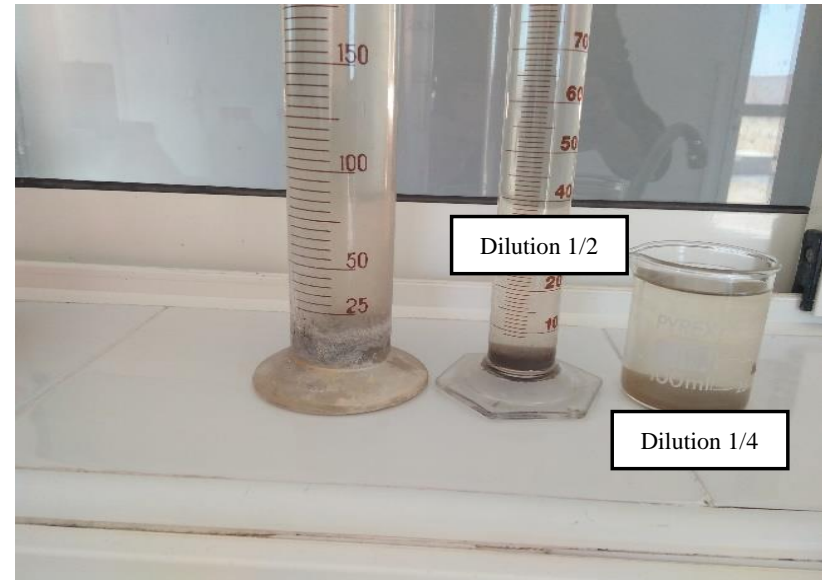

Illustration 2. Measures the sludge index of the aerobic reactor

The results of SI are expressed in $\mathrm{mL} / \mathrm{g}$, the recorded values of our samples vary between $28.57 \mathrm{~mL} / \mathrm{g}, 32.14$ and $54.85 \mathrm{~mL} / \mathrm{g}$, these fluctuations are due to the dilution we have carried out $(1 / 2$ and $1 / 4)$ at the Laboratory level.

SI $<120 \mathrm{~mL}$ : g this indicates very good settling at the secondary settling tank.

\subsection{Monitoring of Recirculating Water}

The recirculation of the sludge from the clarifier to the aeration tank helps maintain a constant bacterial mass in the aeration tank (the sludge should not remain in the clarifier for more than 2 hours). Insufficient recirculation will cause sludge to be stored in the clarifier and promote sludge swelling and sludge discharges.

National and international wastewater treatment plant operators advise to ensure a permanent recirculation flow rate equal to: $150 \%$ of the peak raw water flow.

According to our results recorded at the level of the automation, the recirculating flow for the month of June 2019 represents $140 \%$ of that entered, which will testify to the efficiency of the settling at the level of the scraper, because the clarifier is not a sludge concentrator and no storage is allowed in this structure.

\subsection{Clarity on The Scraper}

By following the measurement of the suspended matter in NTU at the level of the decanted water automatic device, which is a good indicator of the quality of the purified water with a value around 6.14 NTU. So it is useful to look for the presence of a sludge blanket in the clarifier in order to assess the suitability of the sludge for settling in the structure. To do this, the water clarity is monitored weekly, resulting in a purely greater than 60 $\mathrm{cm}$ clarity, which will indicate a good quality of the purified water in this structure.

Lemna minor, the small duckweed, is a species of duckweed, a plant in the Araceae family and the Lemnoideae subfamily (formerly, Lemnaceae family) illustration (3). It is one of the most common and cosmopolitan species of duckweed, which reproduces very quickly when the sun (a species whose development is optimal in full light) and the temperature are suitable. In certain contexts, it has great potential for water purification and as an organic fertilizer, but it can also bioconcentrate certain non-biodegradable pollutants and transfer them to other compartments of the environment.

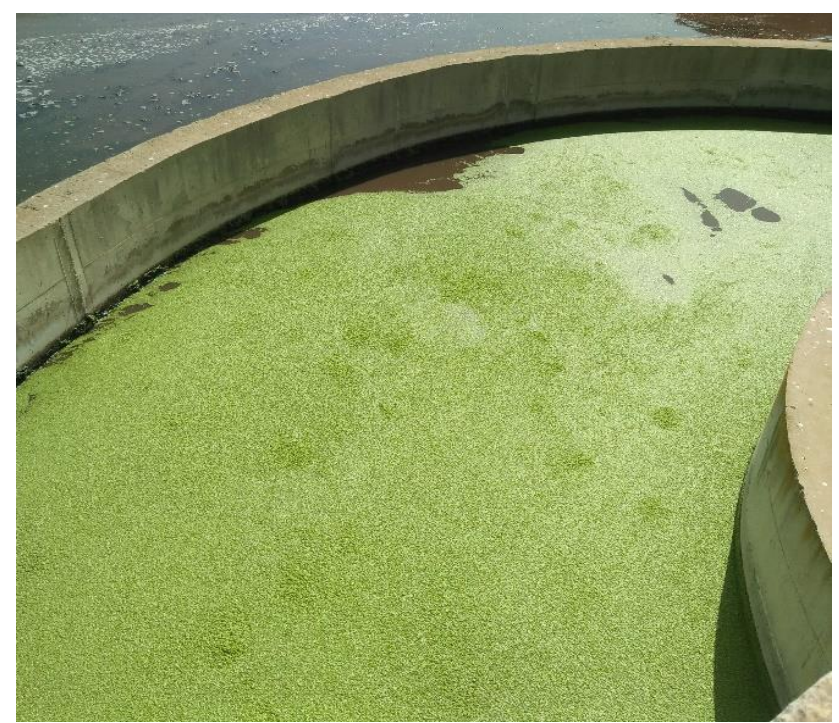

Illustration 3. Lemna minor species from anaerobic basin

Lemna minor easily colonizes fresh waters with a high nitrate rate, rich in organic matter and well lit. Its growth is optimal at a pH between 6.5 and 7.5 (although it tolerates water with a $\mathrm{pH}$ between 5 and 9). Temperatures should be between 6 and $33^{\circ}$ C.

To solve this problem, we proceeded to recover these plants (Lemna Minor species) using a fine medium-sized net made by our team.

\subsection{Entrance Flow to The Station}

The flow is an important factor to measure, it tells us about the quantity of the organic load entered at the station by measuring the pollution indicators namely $\mathrm{BOD}, \mathrm{COD}$, nitrogenous and phosphate derivatives.

The raw water flow rate at the entrance to the station fluctuates between a minimum of $90 \mathrm{~m}^{3} / \mathrm{d}$ and a maximum of $647 \mathrm{~m}^{3} / \mathrm{d}$ with an average of around $340 \mathrm{~m}^{3} / \mathrm{d}$ (figure 2). The minimum value was recorded on August 21 and the maximum value on August 07.

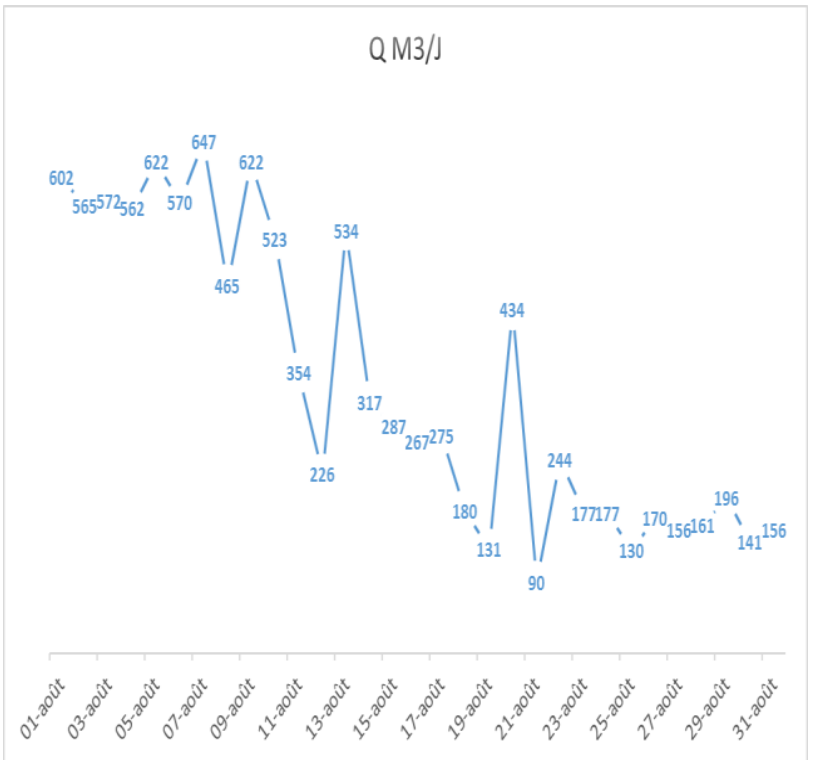

Figure 2. Daily variation in flow rate at the station entrance 


\section{RESULTS AND DISCUSSION}

The results presented below are the fruit of the work of the month of June, carried out at the laboratory level within the Ben Slimane wastewater treatment plant.

\subsection{Daily Variation of Suspended Solids (SS)}

Suspended matter represents all the mineral and organic particles contained in wastewater. Their effects on the physicochemical characteristics of water are very harmful (modification of water turbidity, reduction of light penetration and therefore photosynthesis).

The quantity of matter in suspension, at the inlet, varies between $1,8 \mathrm{~g} / \mathrm{l}$ and $3 \mathrm{~g} / \mathrm{l}$ with a high average of $2,46 \mathrm{~g} / \mathrm{l}$ (Figure 2), at the outlet; it varies between $0,09 \mathrm{~g} / \mathrm{l}$ and $0,22 \mathrm{~g} / \mathrm{l}$ with an average of $0,16 \mathrm{~g} / \mathrm{l}$

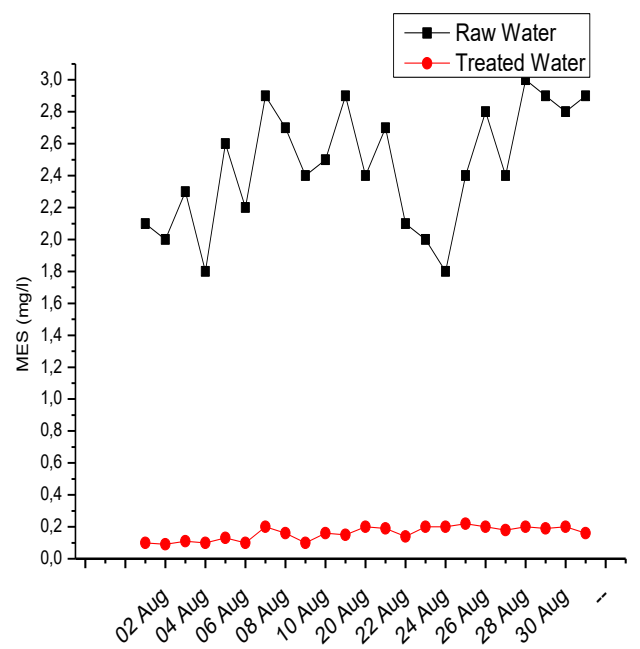

Figure 3. Variation in daily concentrations of suspended solids from the raw and treated effluent

These results are often linked to the significant load of organic and mineral matter generated by the working population, drained by the sewerage collectors connected to the station.

In order to control the purification efficiency of the intensive system used, we calculated the reduction in mineral and colloidal load.

The results obtained illustrated in (Figure 4) show that the reduction values oscillate between $88.88 \%$ and $95.83 \%$. Despite this efficiency, these suspended solids concentrations remain largely exceeded the direct discharge limit concentration.

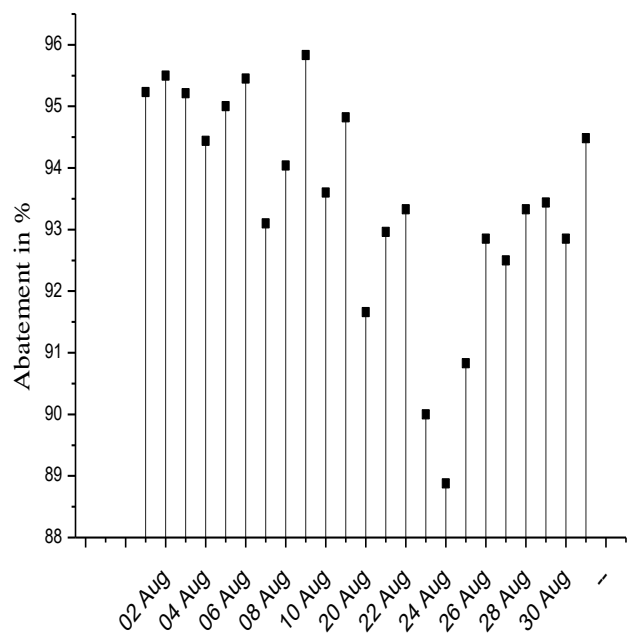

Figure 4. Daily variation of the abatement of suspended solids in $\%$

\subsection{Daily Variation in Biological Oxygen Demand BOD5}

The results of the descriptive analysis shown in Figure 5 show that the monthly inlet BOD5 concentrations fluctuate between $90 \mathrm{mg} \mathrm{O} / 1$ and $179 \mathrm{mg} / \mathrm{l}$, with an average of $357.4 \mathrm{mg} \mathrm{O} / 1$ (Figure 4).

Thus, the output contents are between $14 \mathrm{mg}$ of $\mathrm{O}_{2} / 1$ and $28 \mathrm{mg}$ of $\mathrm{O}_{2} / \mathrm{l}$, with an average of $17.62 \mathrm{mg}$ of $\mathrm{O}_{2} / 1$.

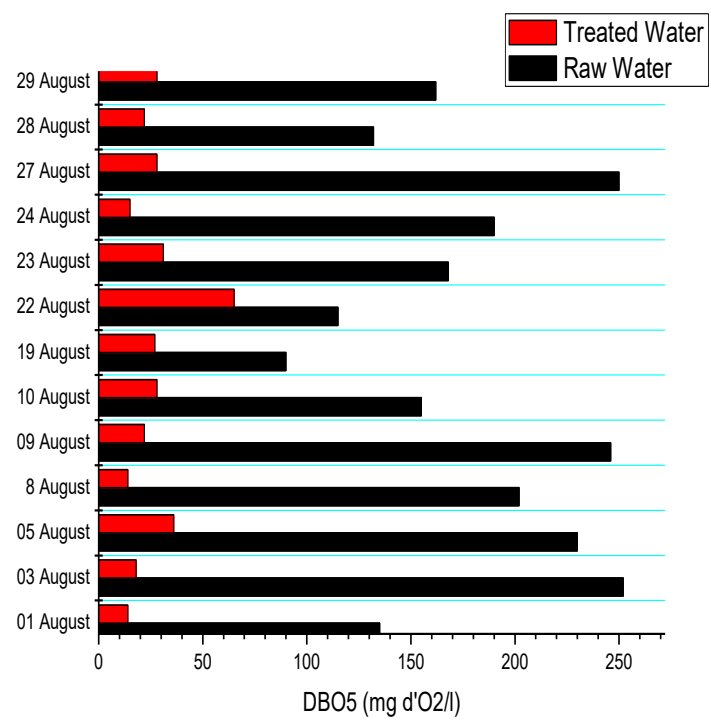

Figure 5. Change in biological oxygen demand concentrations after five days of raw and treated water

The difference between the BOD5 values, at the inlet and at the outlet, passing through the three components (pretreatment, biological basin and settling basins then disinfection by chlorine) which constitute the treatment plant, provides us with information on the reduction rate which reaches up to $92.9 \%$ (figure 6). On the other hand, these recorded values of the BOD5 at the outlet comply with the specific limits for domestic discharge. 


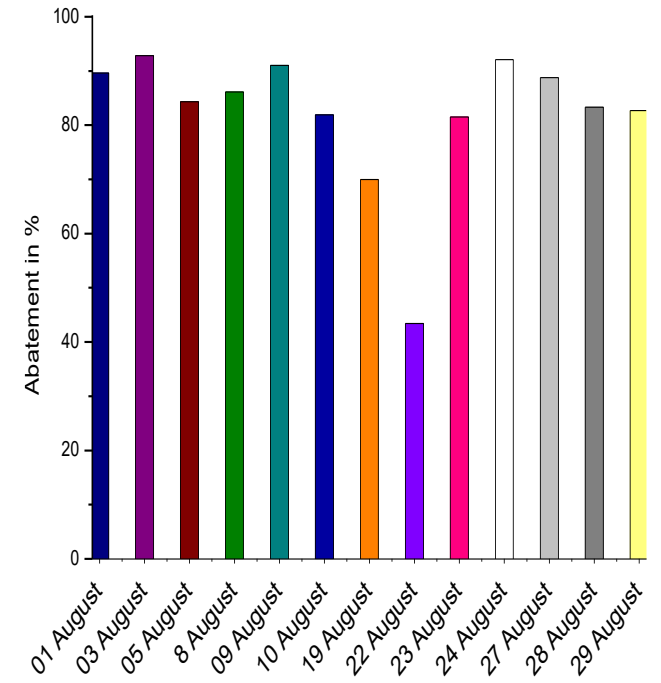

Figure 6. The temporal evolution of the reduction of BOD5 during the month (August)

\subsection{Daily variation in Chemical Oxygen Demand COD}

The COD corresponds to the quantity of dioxygen necessary to oxidize the major part of the organic compounds, biodegradable or not, and certain oxidizable mineral salts.

The chemical oxidation of the reducing materials contained in the water is carried out by an excess of potassium dichromate $\mathrm{K} 2 \mathrm{Cr} 2 \mathrm{O} 7$ in a sulfuric medium, in the presence of silver sulphate (catalyst) and of mercury II sulphate (complexing chlorides) for two hours to a boil. Chemical oxygen demand (COD) is expressed in $\mathrm{mg} / \mathrm{l}$ of oxygen.

The COD values measured at the inlet vary between $290 \mathrm{mg}$ of $\mathrm{O} 2 / 1$ and $950 \mathrm{mg}$ of $\mathrm{O} 2 / 1$ with an average of $497.9 \mathrm{mg}$ of O2/1 and those at the outlet are between $25 \mathrm{mg}$ of $\mathrm{O}_{2} / \mathrm{l}$ and $126 \mathrm{mg}$ $\mathrm{O}_{2} / \mathrm{l}$, with an average of $65.12 \mathrm{mg} \mathrm{O}_{2} / \mathrm{l}$ (Figure 7)

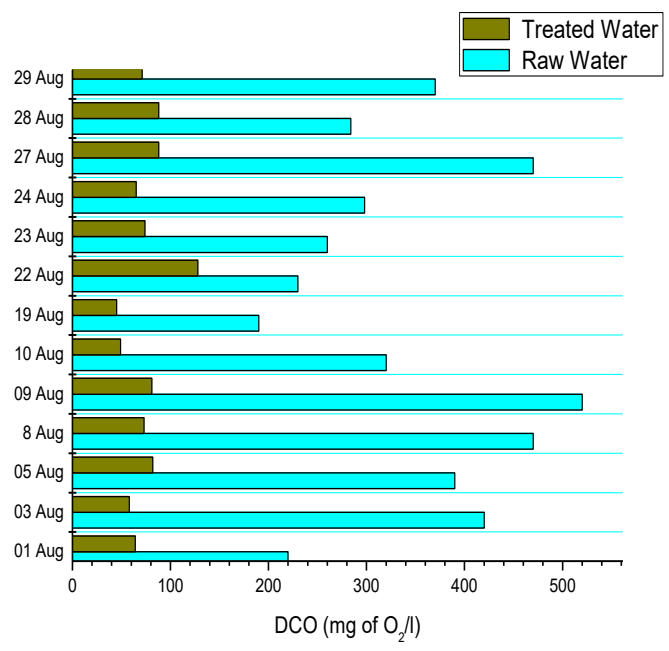

Figure 7. Variation in the concentrations of the chemical oxygen demand of raw and treated water
The average yield is $87.33 \%$. With regard to carbon pollution (Figure 8). Indeed the best deductions are recorded on June 24th, so it reached $92.18 \%$, unlike the low yields recorded during the last ten days with a reduction rate of $84.92 \%$. These values tell us that the studied waters comply with specific limit values for some samples and deviate for others.

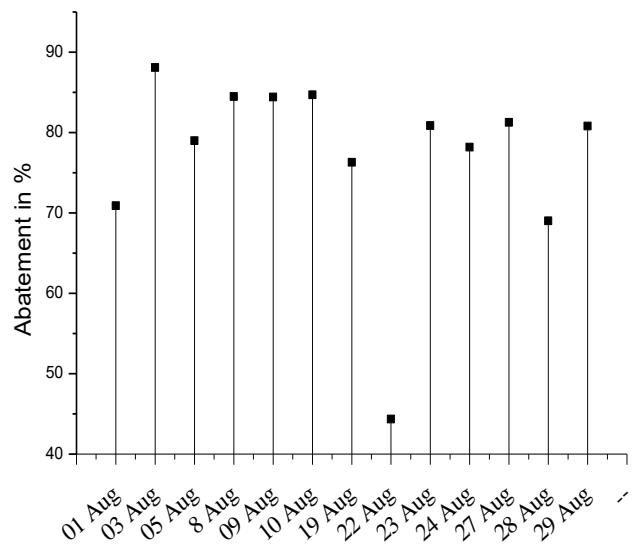

Figure 8 . The temporal evolution of the reduction of the COD during the month (August)

\section{CONCLUSION}

Eutrophication is a major problem for operators in water treatment, especially at the wastewater treatment plant, and in aquatic environments. It is enrichment by nutrients mainly nitrogen and phosphorus ( $\mathrm{N}$ and $\mathrm{P}$ ) used by plants for their growth, also leading to the formation of algae.

The main objective of this work is to study the purification performance of the wastewater treatment plant in the city of Ben Slimane.

The results of this work have shown that this water at the entrance to the station is relatively highly loaded with suspended matter (SM) BOD5 and COD. The degree of abatement between entering and leaving the station exceeds $80 \%$.

\section{ACKNOWLEDGEMENTS}

We sincerely thank all members of the laboratory of agrophysiology, biotechnology, environment and quality for their help and cooperation

\section{REFERENCES}

Hartley, K.J. (2008). Controlling sludge settleability in the oxidation ditch process. Water Res. 42, 1459-1466.

He, D., Chan, S., Qiao, Y., and Guizani, N. (2018). Imminent communication security for smart communities. IEEE Commun. Mag. 56, 99-103.

Martins, A.M., Pagilla, K., Heijnen, J.J., and van Loosdrecht, M.C. (2004). Filamentous bulking sludge - a critical review. Water Res. 38, 793-817. 
Muga, H.E., and Mihelcic, J.R. (2008). Sustainability of wastewater treatment technologies. J. Environ. Manage. 88, 437-447.

Najy, M., Lachhab, M., Taouraout, A., El Qryefy, M., and Belghyti, D. (2019a). Performance of Aluminum and IronBased Coagulants for the Removal of Water Turbidity for Human Consumption in the Cities (Rabat and Casablanca) of Morocco and Dewaterability of Hydroxide Sludge. In The Proceedings of the Third International Conference on Smart City Applications, (Springer), pp. 1154-1166.

Najy, M., Ech-Chafay, H., Elismaili, I., Taouraout, A., and Belghyti, D. (2019b). Treatment of hydroxide discharges from a drinking water treatment plant in the city of Rabat (Morocco). In Proceedings of the 4th International Conference on Smart City Applications, pp. 1-5.

Nancharaiah, Y.V., and Sarvajith, M. (2019). Aerobic granular sludge process: a fast growing biological treatment for sustainable wastewater treatment. Environ. Impact Assess. Green Technol. Environ. Remediat. 12, 57-65.

Nguyen, D.H. (2014). Optimisation de la conception et du fonctionnement des stations de traitement des eaux usées. $\mathrm{PhD}$ Thesis.

Olsson, G. (2012). ICA and me-a subjective review. Water Res. $46,1585-1624$

Renou, S. (2006). Analyse de cycle de vie appliquée aux systèmes de traitement des eaux usées. PhD Thesis. Institut National Polytechnique de Lorraine.

da Silva, M. do C.L. (2008). Effet de la variabilité du fractionnement de la pollution carbonée sur le comportement des systèmes de traitement des eaux usées par boues activées. $\mathrm{PhD}$ Thesis. Institut National Polytechnique de Lorraine. 